Науковий вісник НлтУ України
Scientific Bulletin of UNFU
http://nv.nltu.edu.ua $\begin{array}{r}\text { (c) (i) } \\ \text { ISSN 1994-7836 (print) } \\ \text { ISSN 2519-2477 (online) } \\ \begin{array}{l}\text { https://doi.org/10.15421/40290707 } \\ \text { Article received 03.09.2019 p. } \\ \text { Article accepted 26.09.2019 p. } \\ \text { удк 631.[811.98+535]:633.877 }\end{array}\end{array}$

С. А. Коваль, В. А. Вітенко

Уманський національний університет садівництва, м. Умань, Україна

\title{
УТВОРЕННЯ ДОДАТКОВИХ КОРЕНІВ У СТЕБЛОВИХ ЖИВЦІВ ЯЛИНИ КАНАДСЬКОЇ (ФОРМА КОНІЧНА) ЗАЛЕЖНО ВІД ОБРОБЛЕННЯ РОСТОРЕГУЛЯТИВНОЮ РЕЧОВИНОЮ
}

\begin{abstract}
Наведено результати дослідження утворення та розвитку кореневої системи у стеблових живців ялини канадської (форма конічна) $з$ однорічною деревиною та живців із відрізком дворічної деревини (п'яткою). Встановлено, що кількість коренів, які утворюються у стеблових живців ялини канадської (форма конічна) та їхня загальна довжина залежать від типу живця й оброблення розчинами росторегулятивної речовини. Більша кількість коренів утворюється у живців 3 відрізком дворічної деревини. Довжина коренів у живців цього типу також більша. Виявлено, що найефективнішим для стимулювання утворення додаткових коренів у живців ялини канадської з однорічною деревиною є розчин ІМК з концентрацією 50 мг/л, під впливом дії якої кількість коренів у них становить 17,8 шт. і достовірно переважає контрольний варіант на 2,7 шт. У живців 3 дворічною деревиною кількість адвентивних коренів становить 25,3 шт., перевага над контролем - 4,2 шт. Досліджено, що в усіх варіантах із застосуванням для оброблення живців розчинів IМК одержано достовірне зростання довжини основних коренів порівняно 3 контрольним варіантом. Живці ялини канадської (форма конічна) з дворічною деревиною (п'яткою) формують найбільшу за довжиною кореневу систему, яка має 114,2 см, живці з однорічною деревиною - 96,0 см під впливом оброблення ІМК із концентрацією 50 мг/л.

Ключові слова: однорічний живець; живець з відрізком дворічної деревини (п'яткою); кількість коренів; довжина коренів; концентрація росторегулятивної речовини.
\end{abstract}

Вступ. Завдяки цінним декоративним властивостям ялини часто її використовують для озеленення населених місць. Ялину канадську (Picea canadensis Britt. або Picea qlauca) вирощують як декоративне дерево в усіх областях України. За поширеністю вона поступається тільки ялині європейській (Picea abies Karst.) та ялині колючій (Picea pungens Engelm.) (Bilik, 2005; Kalinichenko, 2003). "Коніка" - найпопулярніша конічна форма ялини канадської, яку вивели дендрологи Редер і Джек у Канаді в 1904 р. Крона - пірамідальна, щільна, густа й пухка, діаметром до 2 м. У 60-річному віці висота дерева може досягати 4 м (Zayachuk, 2008).

Для розмноження особливо цінних видів і форм хвойних рослин з метою збереження їхніх декоративних властивостей, які не передаються потомству під час розмноження насінням, доцільніше використовувати вегетативне розмноження (Graboviy, 2007). Одним із найефективніших методів вегетативного розмноження $\epsilon$ стеблове живцювання. Його теоретичною основою $€$ природна здатність стеблових живців (частин пагона) утворювати адвентивні корені у процесі репродуктивної регенерації (Balabak, 1995; Ivanova, 1982).

Широкому впровадженню в озеленення населених місць ялини канадської та зокрема її конічної форми перешкоджає відсутність достатньої кількості садивного матеріалу та його висока вартість. Для вирішення цієї

актуальної проблеми необхідно розширювати дослідження з удосконалення технології розмноження та вирощування саджанців ялини канадської, зокрема й із застосуванням оброблення розчинами росторегулятивної речовини.

Об'єкт дослідження - закономірності обкорінення стеблових живців і ріст саджанців ялини канадської залежно від типу живця й оброблення різними концентраціями росторегулятивної речовини.

Предмет дослідження - технологія вирощування саджанців ялини канадської (форма конічна) зі стеблових живців.

Матеріал і методи дослідження. Регенераційну здатність стеблових живців ялини канадської (форма конічна) (Picea canadensis Britt. "conica") вивчали в теплиці з пристроєм дрібнодисперсного зволоження. Живці заготовлювали з 15-річних маточних рослин за методикою М. Т. Тарасенка (1991). Для живцювання використовували пагони двох типів: 3 однорічною деревиною та з відрізком дворічної деревини.

Для стимулювання утворення додаткових коренів застосовували водні розчини росторегулятивної речовини ауксинової природи - індолилмасляної кислоти (IMК) з концентраціями 0; 25; 50; 75 мг/л.

Стеблові живці ялини канадської заготовлювали в першій декаді квітня після виходу рослини зі стану спо-

Інформація про авторів:

Коваль Сергій Анатолійович, канд. с.-г. наук, доцент, кафедра лісового господарства. Email: sergiy.koval24@ ukr.net Вітенко Володимир Анатолійович, канд. біол. наук, доцент, кафедра лісового господарства. Email: uman.vitenko@ukr.net Цитування за ДСтУ: Коваль С. А., Вітенко В. А. Утворення додаткових коренів у стеблових живців ялини Канадської (форма конічна) залежно від оброблення росторегулятивною речовиною. Науковий вісник НлтУ України. 2019 , т. 29 , № 7. С. 34-37.

Citation APA: Koval, S. A., \& Vitenko, V. A. (2019). The Influence of Treatment by Growth-Regulating Chemicals on the Additional root Formation Regenerated by Stem Cutting of Canadian Spruce (Conical Form). Scientific Bulletin of UNFU, 29(7), 34-37. https://doi.org/10.15421/40290707 
кою, про що свідчив початок сокоруху і набубнявіння бруньок. Живці нарізували довжиною 5-10 см, видаляли хвою на нижній частині, яка знаходитиметься в субстраті, для запобігання загниванню (рис. 1 і 2), зв'язували в пучки по 25 шт. Морфологічно нижні кінці живців занурювали на 2 см у робочий розчин IMК. У контрольному варіанті застосовували оброблення живців водою. Експозиція оброблення робочими розчинами IMК становила 24 год, після цього їх промивали проточною водою. Висаджування проводили в гряди теплиці за схемою $10 \times 5 \mathrm{~cm}$, заглиблюючи на $2 \mathrm{~cm}$ у торф'яно-піщаний субстрат (співвідношення 1:1).

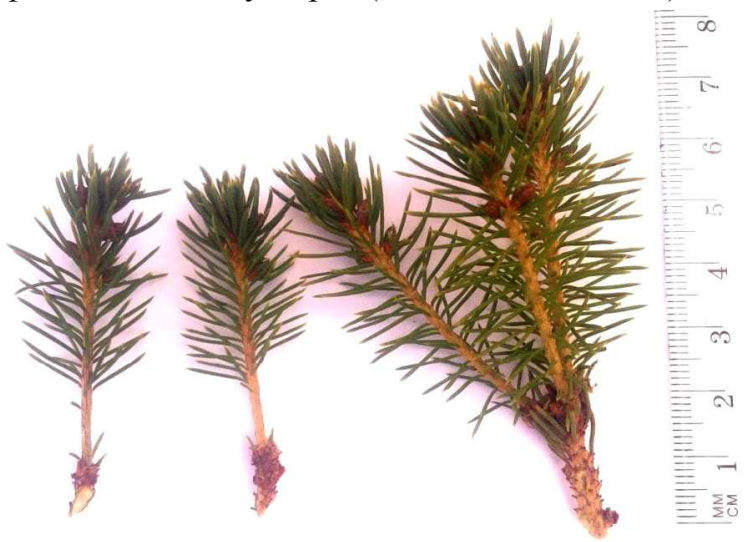

Рис. 1. Живці ялини канадської (форма конічна) з відрізком дворічної деревини

Для обкорінювання стеблових живців ялини канадської використовували умови штучного дрібнодисперсного зволоження. У культиваційній споруді (теплиця ТП 810-25) підтримували сталий режим вологості повітря способом автоматичного регулювання за допомогою штучного водного туману. Середня тривалість одного включення пристрою дрібнодисперсного зволоження становила $15 \mathrm{c}$, інтервал між включеннями 15 хв, що забезпечувало постійну вологість і температуру повітря. Після утворення коренів у живців збільшували інтервал між включеннями пристрою дрібнодисперсного зволоження.

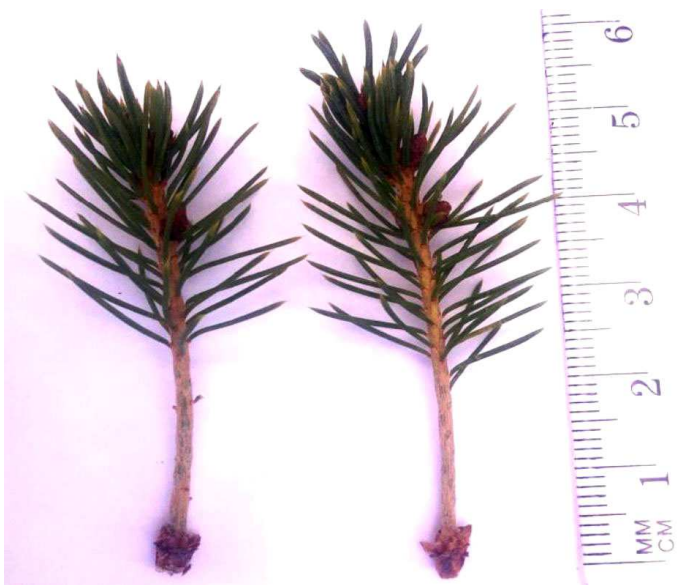

Рис. 2. Живці ялини канадської (форма конічна) з однорічною деревиною

Повторність досліду чотириразова. У кожному повторенні досліджували по 25 живців. Облік обкорінених живців проводили наприкінці вегетаційного періоду. Підраховували кількість основних коренів і вимірювали їхню довжину. Статистичне оброблення результатів здійснювали за Б. О. Доспєховим (1985) методом однофакторного дисперсійного аналізу.
Результати досліджень та їх обговорення. Дослідженнями (Graboviy, 2007; Shpakova, 2001; Koval, 2014) встановлено, що живцювання в оптимальні терміни забезпечує підвищену чутливість живців до оброблення росторегулятивними речовинами, утворення розвиненої кореневої системи та сприяє їхньому інтенсивному росту.

Аналізуючи вплив досліджуваних концентрацій IMК на кількість коренів у вкорінених живців ялини канадської (форма конічна) з однорічним приростом, необхідно відзначити їхню позитивну дію на цей показник (табл. 1).

Табл. 1. Кількість коренів у стеблових живців ялини канадської (форма конічна) з однорічним приростом залежно від оброблення ІМК, шт.

\begin{tabular}{|c|c|c|c|}
\hline \multirow{2}{*}{$\begin{array}{c}\text { Концентрація } \\
\text { ІМК, мг/л }\end{array}$} & \multicolumn{2}{|c|}{ Кількість коренів, шт. } & \multirow{2}{*}{$\begin{array}{c}\text { Середнє за } \\
2017-2018 \text { рр. }\end{array}$} \\
\hline & $2017 \mathrm{p}$. & $2018 \mathrm{p}$. & \\
\hline 0 (вода, контроль) & 14,8 & 15,4 & 15,1 \\
\hline 25 & 15,6 & 16,8 & 16,2 \\
\hline 50 & 17,2 & 18,4 & 17,8 \\
\hline 75 & 16,0 & 17,4 & 16,7 \\
\hline $\mathrm{HIP}_{05}$ & 1,54 & 2,83 & \\
\hline
\end{tabular}

У досліді найбільш сприятливим для утворення додаткових коренів у цього типу живців ялини канадської виявився варіант 3 обробленням IMК 3 концентрацією 50 мг/л. Під впливом оптимальної концентрації кількість коренів становила 17,8 шт. у середньому за 2017 2018 pр. і достовірно переважала контрольний варіант на 2,7 шт.

Вплив решти досліджуваних концентрацій IMК не цей показник виявився неістотним, оскільки перевага над контролем не перевищувала найменшу істотну різницю (НІР 05$)$.

Вплив досліджуваного фактора "концентрація IMК" на кількість основних коренів у вкорінених стеблових живців ялини канадської (форма конічна) з однорічним приростом становить 40-49\%, що свідчить про його незначну силу впливу на цей показник.

За даними проведених досліджень, кількість коренів у стеблових живців ялини канадської (форма конічна) 3 дворічною деревиною також залежала від оброблення IMK. Аналізуючи дані табл. 2, необхідно зазначити, що кількість основних коренів у живців цього типу зростала в усіх варіантах із використанням для оброблення розчинів росторегулятивної речовини, порівняно з контрольним, протягом 2017-2018 рр. досліджень. Ми виявили, що в цих варіантах відбулося збільшення кількості коренів на 1,3-4,2 шт. в середньому за період досліджень порівняно з контролем. Але тільки у варіанті із застосуванням розчину IMК із концентрацією 50 мг/л виявили істотне збільшення цього показника за період досліджень порівняно з контрольним варіантом.

Табл. 2. Кількість коренів в укорінених живців ялини канадської (форма конічна) 3 дворічною деревиною залежно від оброблення ІМК, шт.

\begin{tabular}{|c|c|c|c|}
\hline Концентрація & \multicolumn{2}{|c|}{ Кількість коренів, шт. } & Середнє за \\
\cline { 2 - 3 } ІМК, мг/л & 2017 р. & 2018 р. & 2018 pp. \\
\hline 0 (вода, контроль) & 20,5 & 21,7 & 21,1 \\
\hline 25 & 21,3 & 23,5 & 22,4 \\
\hline 50 & 24,2 & 26,4 & 25,3 \\
\hline 75 & 22,4 & 23,6 & 23,0 \\
\hline HІР $_{05}$ & 3,30 & 4,00 & \\
\hline
\end{tabular}

Кількість коренів, які утворились у живців ялини канадської в цьому варіанті зросла, порівняно з контролем, у 1,2 раза або на 4,2 шт. у середньому за 20172018 pp. 
Сила впливу досліджуваного фактора "концентрація IMK" на кількість коренів у стеблових живців ялини канадської (форма конічна) 3 дворічною деревиною виявилася незначною, як і на живці з однорічним приростом, і становила 27-37\%.

Отже, порівнюючи результати впливу росторегулятивної речовини на кількість коренів, які регенерували стеблові живці ялини канадської (форма конічна) 3 однорічною та дворічною основами, виявлено, що у живців із дворічною деревиною утворилося більше коренів у оптимальному варіанті - 25,3 шт., проти 17,8 шт. - у живців 3 однорічною деревиною.

Згідно з результатами дослідження впливу концентрацій IMК на довжину основних коренів у вкорінених стеблових живців ялини канадської (форма конічна) 3 однорічною деревиною, які відображено в табл. 3, застосування робочих розчинів із всіма досліджуваними концентраціями, порівняно з обробленням водою (контроль), збільшують довжину коренів першого і другого порядків галуження у живців цього типу.

Найбільшу довжину новоутворених коренів зафіксували у варіанті із застосуванням розчину IМК з концентрацією 50 мг/л. Цей показник становить у середньому за період досліджень 96,0 см, що на 18,3 см або в 1,24 раза більше за контрольний варіант.

Табл. 3. Довжина коренів у стеблових живців ялини канадської (форма конічна) з однорічним приростом залежно від оброблення ІМК, см

\begin{tabular}{|c|c|c|c|}
\hline Концентрація & \multicolumn{2}{|c|}{ Довжина коренів, см } & Середнє за \\
\cline { 2 - 3 } ІМК, мг/л & 2017 р. & 2018 р. & 77,7 \\
\hline 0 (вода, контроль) & 76,9 & 78,5 & 77,7 \\
\hline 25 & 82,7 & 85,2 & 84,0 \\
\hline 50 & 94,6 & 97,4 & 96,0 \\
\hline 75 & 83,2 & 86,6 & 84,9 \\
\hline HІР $_{05}$ & 4,65 & 4,55 & \\
\hline
\end{tabular}

Дія розчинів IMК 3 концентраціями 25 і 75 мг/л на досліджуваний показник виявилася також ефективною. Перевага над контрольним варіантом була достовірною протягом 2017-2018 pр. і становила 6,3-7,2 см.

Вплив досліджуваного фактора "концентрація IMK" на довжину основних коренів у вкорінених стеблових живців ялини канадської (форма конічна) з однорічним приростом становив 88-89\%, що свідчить про його значну силу впливу на цей показник.

Аналізуючи результати дослідження довжини основних коренів у стеблових живців ялини канадської (форма конічна) з відрізком дворічної деревини (рис. 3), варто зазначити, що цей показник у них залежав від оброблення росторегулятивною речовиною.

В усіх варіантах із застосуванням для оброблення живців ялини канадської досліджуваних розчинів IMК одержали достовірне зростання у них довжини основних коренів порівняно з контрольним варіантом. У середньому за період дослідження вона в цих варіантах на 9,4-11,0 см переважала контроль.

Згідно 3 даними табл. 4, оптимальним виявився варіант із використанням розчину IMК із концентрацією 50 мг/л, у якому спостерігали істотне збільшення цього показника за весь період досліджень як порівняно 3 контролем, так і з концентраціями 25 і 75 мг/л. У цьому варіанті кількість коренів, що утворилась у вкорінених живців ялини канадської (форма конічна), зросла, порівняно $з$ контрольним варіантом (оброблення водою), в 1,22 раза пересічно за 2017-2018 pp.

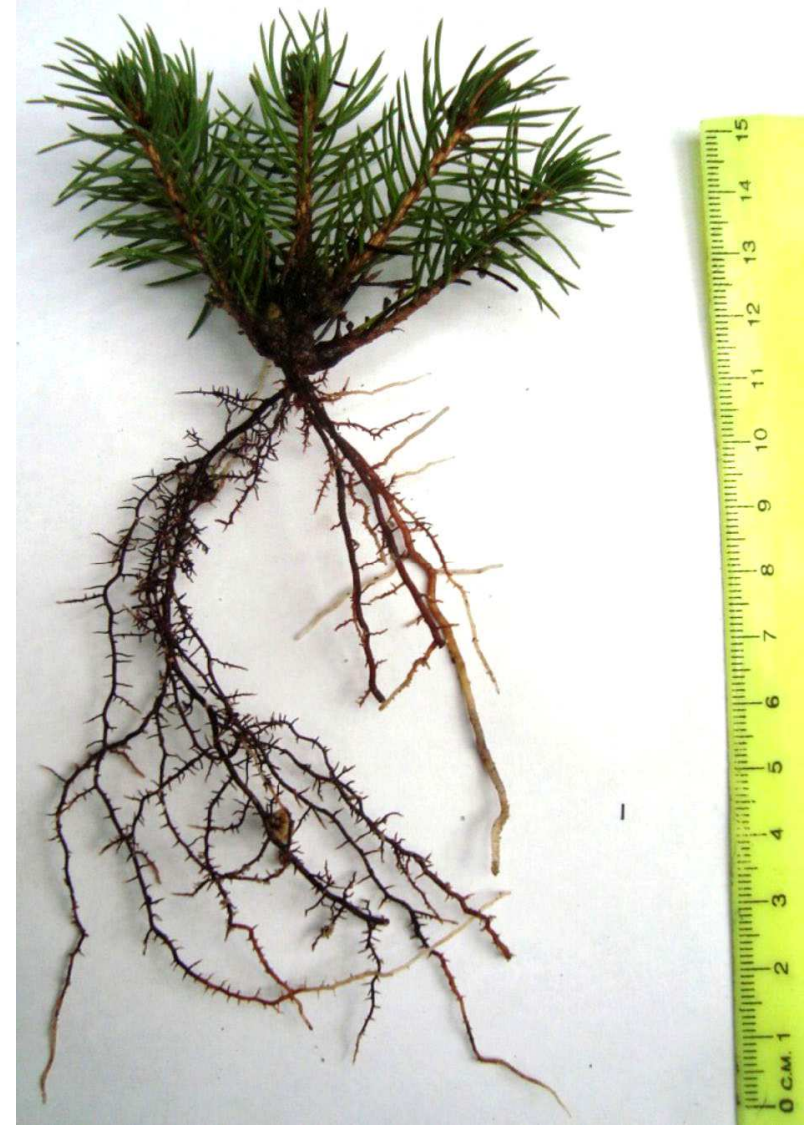

Рис. 3. Обкорінений живець ялини канадської (форма конічна) з відрізком дворічної деревини

Табл. 4. Довжина коренів у стеблових живців ялини канадської (форма конічна) з дворічною деревиною залежно від оброблення ІМК, см

\begin{tabular}{|c|c|c|c|}
\hline \multirow{2}{*}{$\begin{array}{c}\text { Концентрація } \\
\text { IMК, мг/л }\end{array}$} & \multicolumn{2}{|c|}{ Довжина коренів, см } & \multirow{2}{*}{$\begin{array}{c}\text { Середнє за } \\
2017-2018 \text { рр. }\end{array}$} \\
\hline & 2017 p. & $2018 \mathrm{p}$. & \\
\hline $\begin{array}{c}0 \text { (вода, } \\
\text { контроль) }\end{array}$ & 91,8 & 94,5 & 93,2 \\
\hline 25 & 101,3 & 103,8 & 102,6 \\
\hline 50 & 112,5 & 115,9 & 114,2 \\
\hline 75 & 103,4 & 108,3 & 105,8 \\
\hline $\mathrm{HIP}_{05}$ & 3,04 & 6,75 & \\
\hline
\end{tabular}

Сила впливу досліджуваного фактора "концентрація IMК" на довжину основних коренів у стеблових живців ялини канадської (форма конічна) 3 дворічною деревиною виявилася значною і становила 79-86 \%.

Таким чином, довжина коренів, що утворилися у стеблових живців ялини канадської (форма конічна) 3 однорічним приростом і з відрізком дворічної деревини під впливом ІМК, значно відрізнялася. Це пояснюємо тим, що живці з дворічною деревиною утворили більшу кількість коренів порівняно 3 живцями 3 однорічним приростом і мали більшу площу фотосинтезуючої поверхні. Живці ялини канадської $з$ дворічною деревиною формували найбільшу за довжиною кореневу систему (114,2 см) під впливом оброблення розчином IMК із концентрацією 50 мг/л, а живці з однорічним приростом $-96,0$ см.

\section{Висновки:}

1. Порівнюючи результати впливу росторегулятивної речовини (IMК) на кількість коренів, які регенерували стеблові живці ялини канадської (форма конічна) з однорічною та дворічною деревиною, варто зазначити, що у живців із дворічною деревиною в оптимальному варіанті утворюється більше коренів - 25,3 шт., проти 17,8 шт. у живців з однорічною деревиною. 
2. Найефективнішим для стимулювання утворення додаткових коренів у живців ялини канадської з однорічною деревиною є розчин ІМК з концентрацією 50 мг/л. Під впливом дії цієї концентрації кількість коренів у них становить 17,8 шт. і достовірно переважає контрольний варіант на 2,7 шт. У живців 3 дворічною деревиною кількість коренів становить 25,3 шт., перевага над контролем - 4,2 шт.

3. У всіх варіантах із застосуванням для оброблення живців розчинів IMК одержано достовірне зростання довжини основних коренів порівняно з контрольним варіантом. Живці ялини канадської (форма конічна) 3 дворічною деревиною (п'яткою) формують найбільшу за довжиною кореневу систему, яка має 114,2 см, живці $з$ однорічною деревиною - 96,0 см під впливом оброблення IMК із концентрацією 50 мг/л.

\section{Перелік використаних джерел}

Balabak, A. F. (1995). Korenevlasne rozmnozhennia sadovykh roslyn v Lisostepu Ukrainy. Abstract of Doctoral Dissertation for Agricultural Sciences. Kiev, 46 p. [In Ukrainian].

Bilyk, O. V. (2005). Introduktsiia vydiv rodu Picea Dietr. v Natsionalnomu dendrolohichnomu parku "Sofiivka" NAN Ukrainy. $A v$ - tokhtonni ta introdukovani Roslyny Ukrainy, 81-98. Kiev: Akademperiodyka. [In Ukrainian].

Dospekhov, B. A. (1985). Metodika polevogo opyta. Moscow: Kolos, 351 p. [In Russian].

Hrabovyi, V. M. (2007). Vehetatyvne rozmnozhennia yalyny ta shliakhy praktychnoho vykorystannia otrymanoho sadyvnoho materialu v zelenomu budivnytstvi. Naukovyi visnyk NAU, 17(4), 31-35. Kiev. [In Ukrainian].

Ivanova, Z. Ia. (1982). Biologicheskie osnovy i priemy vegetativnogo razmnozheniia drevesnykh rastenii steblevymi cherenkami. Kiev: Scientific thought, 287 p. [In Russian].

Kalinichenko, O. A. (2003). Dekoratyvna dendrolohiia. Kiev: Higher school, 199 p. [In Ukrainian].

Koval, S. A. (2014). Utvorennia dodatkovykh koreniv u steblovykh zhyvtsiv tui zakhidnoi (forma kolonopodibna) zalezhno vid obroblennia rostorehuliatyvnoiu rechovynoiu. Scientific Bulletin of $U N$ $F U, 24(04), 85-91$. [In Ukrainian].

Shpakova, O. H. (2001). Zhyvtsiuvannia introdukovanykh khvoinykh roslyn v umovakh pivdennoho skhodu Ukrainy. Materialy XI zizdu Ukr. botan. tovarystva, (p. 444). Kharkiv: B. v. [In Ukrainian].

Tarasenko, M. T. (1991). Zelenoe cherenkovanie sadovykh i lesnykh kultur. Moscow: Publishing House TSKhA, 272 p. [In Russian].

Zaiachuk, V. Ya. (2008). Dendrolohiia. Lviv: Apriori, 656 p. [In Ukrainian].

S. A. Koval, V. A. Vitenko

Uman National University of Horticulture, Uman, Ukraine

\section{THE INFLUENCE OF TREATMENT BY GROWTH-REGULATING CHEMICALS ON THE ADDITIONAL ROOT FORMATION REGENERATED BY STEM CUTTING OF CANADIAN SPRUCE (CONICAL FORM)}

To solve the problem of the lack of enough amount of planting material of Canadian spruce and, in particular, its conical shape, to reduce its cost, it is necessary to expand research on improving the technology of propagation and growing seedlings of Canadian spruce, including the use of solutions of growth-regulating substances with solutions. The regenerative ability of stem cuttings of Canadian spruce, conical form (Picea canadensis Britt. "Conica") was studied in a greenhouse TP 810-25 with a device for fine humidification. Cuttings were harvested from 15-year-old uterine plants according to the method of M. T. Tarasenko, 1991. Two types of shoots were used for cuttings: with annual wood and with a piece of biennial wood. To stimulate the formation of additional roots, aqueous solutions of an auxin-based growth-regulating substance, indolylbutyric acid (IBA) with concentrations of $0 ; 25 ; 50$; $75 \mathrm{mg} / 1$ were used. The repetition of the experiment is fourfold. In each repetition, 25 cuttings were examined. The accounting of rooted cuttings was carried out at the end of the growing season. The number of main roots was counted and their length was measured. Comparing the results of the effect of growth-regulating substance (IBA) on the number of roots that regenerated the stem cuttings of Canadian spruce f. conical with annual and biennial wood, it should be noted that cuttings with biennial wood in the optimal form produce more roots - 25.3 pieces, versus 17.8 pieces in cuttings with one-year wood. Under the influence of IBA solution with a concentration of $50 \mathrm{mg} / \mathrm{l}$, the number of additional roots for Canadian spruce cuttings with annual wood is 17.8 pieces and significantly exceeds the control variant by 2.7 pieces. Cuttings with biennial wood form 25.3 roots, which exceeds the control by 4.2 pieces. The largest length of newly formed roots was recorded in the variant using a IBA solution with a concentration of $50 \mathrm{mg} / \mathrm{l}$, where this indicator in cuttings with a year old wood averages $96.0 \mathrm{~cm}$ during the study period, which is $18.3 \mathrm{~cm}$ more than the control variant. In cuttings of Canadian spruce with biennial wood, the longest root system is $114.2 \mathrm{~cm}$, which is $11.0 \mathrm{~cm}$ more than in the control, is also formed in this variant. In all variants using IBA solutions to stimulate root formation, a significant increase in the length of the main roots was obtained in comparison with the control variant.

Keywords: annual cuttings; cuttings with a two-year-old piece of wood (heel); number of roots; root length; concentration of growth-regulating substance. 